\title{
Chemical Composition and Gas Production Substrates of Maize Cobs Treated with Combinations of Urea and Wood Ash
}

\section{Abdulrazaq ABDULAZEEZ1, Christopher Mareledi TSOPITO ${ }^{2}$, Othusitse Ricky MADİBELA ${ }^{2}$}

\author{
${ }^{1}$ Federal College of Education (Technical) Gusau, Zamfara State, Nigeria. \\ ${ }^{2}$ Department of Animal Science, Faculty of Animal and Veterinary Sciences, \\ Botswana University of Agriculture and Natural Resources. Gaborone, Botswana
}

Abdulrazaq ABDULAZEEZ, ORCID No:0000-0001-5627-6135,Christopher Mareledi TSOPITO, ORCID No:0000-0003-1965-164X, Othusitse Ricky MADİBELA, ORCID No:0000-0003-0450-3505

\begin{tabular}{|c|c|}
\hline ARTICLE INFO & A BSTRACT \\
\hline $\begin{array}{l}\text { Research Article } \\
\text { Summarised from PhD thesis and } \\
\text { also presented at the } 11^{\text {th }} \\
\text { International Animal Science } \\
\text { Conference, Cappadocia,Turkey. } \\
\text { Received : } 19.03 .2021 \\
\text { Accepted : } 11.06 .2021\end{array}$ & 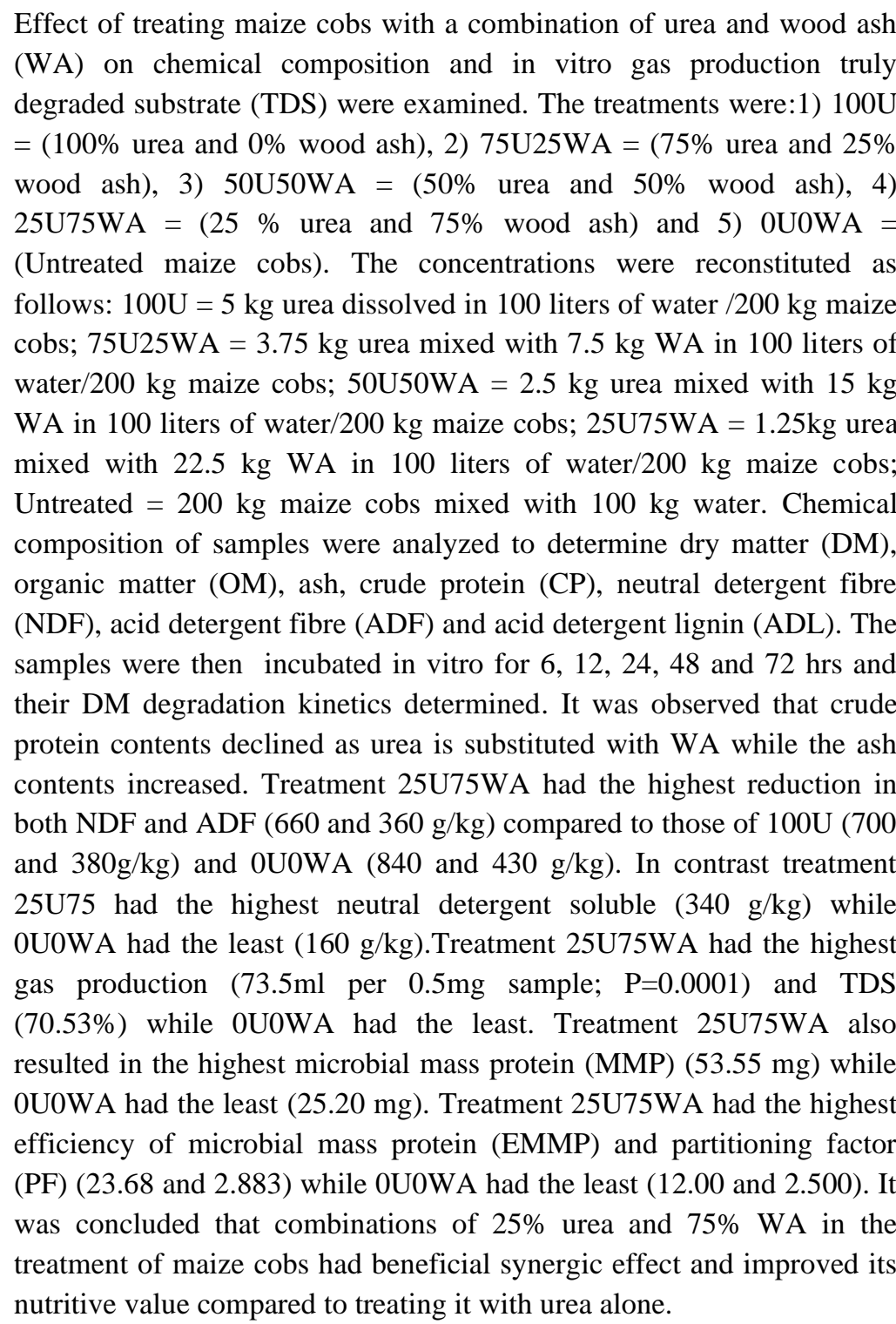 \\
\hline
\end{tabular}




\section{Üre ve Odun Külü Kombinasyonları ile İşlenmiş Mısır Koçanı'nın Kimyasal Bileşimi ve Gaz Üretimi}

\begin{tabular}{|c|c|}
\hline MAKALE BİLGİS İ & Ö Z E T \\
\hline Araştırma Makalesi & \multirow{18}{*}{ 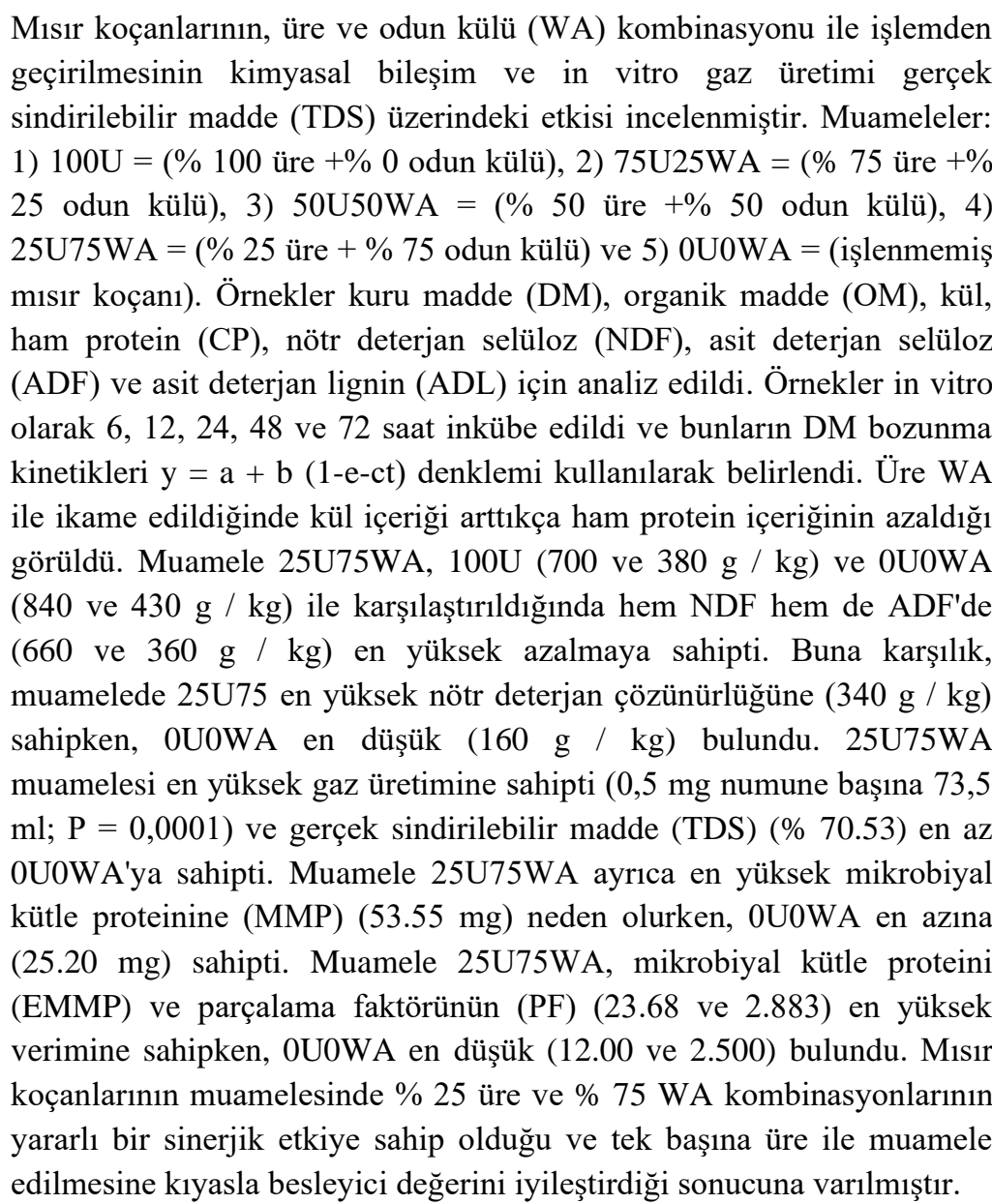 } \\
\hline Doktora tezinden özetlenmis ve & \\
\hline ayrica 11. Uluslararası Hayvan & \\
\hline $\begin{array}{l}\text { Bilimi Konferansında sunulmuştur, } \\
\text { Kanodokva Türkive }\end{array}$ & \\
\hline & \\
\hline Geliş: 19.03 .2021 & \\
\hline Kabul: 11.06.2021 & \\
\hline Anahtar Kelimeler & \\
\hline $\begin{array}{l}\text { Gerçek sindirilebilir madde } \\
\text { mikrobiyal kütle protein }\end{array}$ & \\
\hline Parçalama faktörü & \\
\hline Bitkisel artık & \\
\hline * Sorumlu Yazar & \\
\hline azeezrazaq70@gmail.com & \\
\hline & \\
\hline & \\
\hline & \\
\hline & \\
\hline & \\
\hline
\end{tabular}

\section{Introduction}

Crop residues are leftovers of crop harvest and threshing, they also differ from byproducts of processing like oil cakes, bran etc (Nordblom\&Shomo, 1995). Allen (1995) reported that many crop residues including maize cobs are low in protein and have highly lignified cell walls that reduce intake and digestibility. Most of these crop residues including maize cobs are always left in the field after harvest and sometimes burnt; however, they could be collected and stored for feeding livestock during the dry season when feeds are scarce. Various techniques are being used to improve the nutritive values of crop residues and one of the most effective and popular method is urea treatment (Chenost, 1995), however, urea is mostly imported in Africa hence beyond the reach of poor resource farmers (Abdulazeez et al., 2016). Apart from the cost, another shortcomings associated with urea is its contribution to environmental pollution when converted to ammonia (Abdulazeez et al., 2016). Wood ash had also been used in the treatment of crop residues as reported by several authors such as 
Adebowale et al. (1991); Nolte et al. (1987); Rahman et al. (2009); Solomon et al. (2012). The advantage of wood ash over urea is that it is freely available at household level without cost and rich in minerals, however, its major disadvantage is nitrogen deficiency useful to rumen microbes for fibre digestion (Abduazeez et al., 2016).

Investigations on use of urea (Preston, 1985; Chenost, 1995; Fall et al., 1989) or wood ash (Adebowale et al., 1991; Nolte et al., 1987; Rahman et al., 2009; Solomon et al., 2012) in the treatment of crop residues have been documented, however, information on combination of both in crop residue treatments is lacking. It is expected that when urea and wood ash are combined in crop residue treatments, cost would be reduced. Also both minerals and nitrogen present in wood ash and urea respectively would be incorporated into the crop residues being treated. The objectives of this research was to investigate the effect of treating maize cobs with a combination of urea and wood ash on chemical composition and truly degraded substrate (TDS) parameters of maize cobs.

\section{Materials and Methods}

The research was carried out at Botswana University of Agriculture and Natural Resources, Content Farm, Sebele, Gaborone, Botswana. Maize cobs used for the research were sourced from Molepolele village which is $70 \mathrm{~km}$ from the university and ground using a $4 \mathrm{~mm}$ sieve. In all cases, 5\% urea and 30\% wood ash were dissolved in $100 \mathrm{ml}$ of water (w/v) $1200 \mathrm{~g}$ ground maize cobs (Nolte et al., 1987) were used as a standard for the treatment. The treatments were as follows: 100U (100\% urea and $0 \%$ wood ash), 75U25WA (75\% urea and $25 \%$ wood ash), 50U50WA (50\% urea and 50\% wood ash), 25U75WA (25\% urea and 75\% wood ash) 0U0WA (Untreated maize cobs). The samples were then stored in air-tight plastic bags for 7 days at temperature of $37^{\circ} \mathrm{C}$ (Sundstol., 1985). After the seventh day, chemical composition of the treated samples were then determined. The untreated maize cobs were only wetted and left to dry as they were bound to go moldy when stored in air- tight plastics. The concentrations were reconstituted as follows:

$100 \mathrm{U}=5 \mathrm{~kg}$ urea dissolved in 100 liters of water $/ 200 \mathrm{~kg}$ maize cobs.

$75 \mathrm{U} 25 \mathrm{WA}=3.75 \mathrm{Kg}$ urea mixed with $7.5 \mathrm{~kg}$ WA in 100 liters of water $/ 200 \mathrm{~kg}$ maize cobs. $50 \mathrm{U} 50 \mathrm{WA}=2.5 \mathrm{~kg}$ urea mixed with $15 \mathrm{~kg}$ WA in 100 liters of water $200 \mathrm{~kg}$ maize cobs. $25 \mathrm{U} 75 \mathrm{WA}=1.25 \mathrm{~kg}$ urea mixed with $22.5 \mathrm{~kg}$ WA in 100 liters of water $200 \mathrm{~kg}$ maize cobs. Untreated $=200 \mathrm{~kg}$ maize cobs mixed with $100 \mathrm{~kg}$ water.

\section{Laboratory Analysis of Samples}

In determining the chemical composition of the samples, dry matter was determined by drying samples in forced air oven at $60^{\circ} \mathrm{C}$ for $24 \mathrm{hr}$ (DM, ID number 930.15) while OM (OM, ID number 942.05) and ash were obtained by difference in weight after ignition at $550^{\circ}$ $\mathrm{C}$ in a muffle furnace (Muffle Furnace Size 3, Gallenkamp, UK). ANKOM fiber analyzer was used to determine NDF, ADF and ADL (Ankom Technology Corporation, Fairport, NY, USA) according to the procedure of Van Soest et al, (1991). Sodium sulphite and alpha amylase were also added in the analysis of NDF. Nitrogen was determined by the Kjeldahl method according to AOAC (1999) (ID number 955.04) while CP was determined by multiplying $\mathrm{N}$ by 6.25 (ID number 954.01). 


\section{In vitro Gas Production}

Prior to incubation of feed samples in calibrated glass syringes with rumen fluid, they were milled using $1 \mathrm{~mm}$ sieve (Menke $\&$ Steingass, 1988). The rumen fluid was obtained from two fistulated steers fed commercial concentrate mixed with crushed corn cobs. They were fed twice daily ( $8 \mathrm{am}$ and $4 \mathrm{pm}$ ) for three days prior to collection of rumen fluid. After collection of the rumen liquor in a thermo flask lined with four layered cheese clothes, it was then flushed with carbon dioxide in order to create an anaerobic conditions needed by rumen microorganisms. Samples $(500 \mathrm{mg})$ were weighed in triplicates into calibrated glass syringes of $100 \mathrm{ml}$ and then pre warmed at $39^{\circ} \mathrm{C}$ followed by injection of $30 \mathrm{ml}$ rumen fluid-buffer $(2: 1$ $\mathrm{v} / \mathrm{v})$ mixture into each syringe. The introduction of the rumen fluid into the syringe was done with $\mathrm{CO}_{2}$ flushing followed by incubation in a water bath at $39^{\circ} \mathrm{C}$. The buffer used was made up of: $\mathrm{A}=\mathrm{MgSO}_{4} \cdot \mathrm{H}_{2} \mathrm{O}+\mathrm{NaCl}+\mathrm{KH}_{2} \mathrm{SO}_{4}+\mathrm{CaCl}_{2} \cdot \mathrm{H}_{2} \mathrm{O}+$ Urea and $\mathrm{B}=\mathrm{NaSO}_{4} \cdot 9 \mathrm{H}_{2} \mathrm{O}+$ $\mathrm{NaCO}_{3}$. The gases produced were then recorded at intervals of 6, 12, 24, 48 and 72 hours.

The procedure outlined by Makkar, (2010) was employed in the determination of TDS. The residues left after 72 hours incubation in the glass syringes were treated with NDF solution in a beaker for one hour. The residues were then filtered into a crucible, washed with hot water and then oven dried overnight at $100^{\circ} \mathrm{C}$. Weights of empty crucibles were then subtracted from the weight of crucibles plus undegraded feed residues in order to determine the weight of the undegraded feed sample. The undegraded samples were then transferred to the muffle furnace and ashed at $550^{\circ} \mathrm{C}$. In vitro truly TDS parameters were then determined according to the procedure outlined by Makkar, (2010) as follows:

$\begin{array}{ll}\text { Weight of undegraded residue } & =\mathrm{a}(\mathrm{mg}) \\ \text { Weight of ash } & =\mathrm{b}(\mathrm{mg}) \\ \text { Truly undegraded organic matter } & =\mathrm{a}-\mathrm{b} \\ (500 * \mathrm{DM} \% / 100)(1-\mathrm{ash} \% / 100) & =\mathrm{c}(\mathrm{mg}) \\ \% \text { organic matter digestibility } & =(\mathrm{a}-\mathrm{b}) 100 / \mathrm{c} \\ \text { Microbial mass production }(\mathrm{mg}) & =(\mathrm{a}-\mathrm{b})-2.2 \mathrm{GP}_{24 \mathrm{hr}} \\ \text { Efficiency of microbial mass production } & =\left((\mathrm{a}-\mathrm{b})-2.2 \mathrm{GP}_{24 \mathrm{hr}}\right) / \mathrm{a}-\mathrm{b} \\ \text { Partitioning factor } & =\mathrm{c}-(\mathrm{a}-\mathrm{b}) / \mathrm{GP}_{24 \mathrm{hr}} \\ \mathrm{ME}(\mathrm{MJ} / \mathrm{Kg} \mathrm{DM}) & =2.20+0.136 \mathrm{GP}_{24 \mathrm{~h}}+0.057 \mathrm{CP} \\ 2.2 & =\text { Stoichiometric factor } \\ \mathrm{GP}_{24 \mathrm{hr}} & =\text { Gas production at } 24 \text { hours }\end{array}$

\section{Statistical Analysis}

Data generated from chemical composition and TDS were analyzed using the general linear models (GLM) procedure of SAS (2002) and means separated using Duncan's multiple range test (Steel and Torrie, 1984).

\section{Results}

The chemical composition of untreated and treated maize cobs are shown in Table 1. The untreated maize cobs (0U0WA) had the highest dry matter (DM) content of $952 \mathrm{~g} / \mathrm{kg}$ and 
differed significantly $(\mathrm{P}=0.0068)$ from the treated (100U, 75U25WA, 50U50WA and 25U75WA. The DM contents of all the treated cobs were similar

Table 1. Chemical composition $(\mathrm{g} / \mathrm{kg})$ of untreated and treated maize cobs

Tablo 1. İşlenmemiş ve işlenmiş misır koçanlarının kimyasal bileşimi $(\mathrm{g} / \mathrm{kg})$

\begin{tabular}{llllllll}
\hline $\begin{array}{l}\text { Chemical } \\
\text { composition } \\
(\mathrm{g} / \mathrm{kg})\end{array}$ & \multicolumn{7}{c}{ Types of treatment } \\
\hline & $100 \mathrm{U}$ & $75 \mathrm{U} 25 \mathrm{WA}$ & $50 \mathrm{U} 50 \mathrm{WA}$ & $25 \mathrm{U} 75 \mathrm{WA}$ & $0 \mathrm{U} 0 \mathrm{WA}$ & SE & P values \\
\hline $\mathrm{DM}$ & $795.0^{\mathrm{b}}$ & $785.0^{\mathrm{b}}$ & $790.0^{\mathrm{b}}$ & $775.0^{\mathrm{b}}$ & $952.0^{\mathrm{a}}$ & 23.28 & 0.0068 \\
$\mathrm{ASH}$ & $37.74^{\mathrm{d}}$ & $79.59^{\mathrm{c}}$ & $123.5^{\mathrm{b}}$ & $170.8^{\mathrm{a}}$ & $34.11^{\mathrm{d}}$ & 17.42 & $<0.0001$ \\
$\mathrm{OM}$ & $962.3^{\mathrm{a}}$ & $920.4^{\mathrm{b}}$ & $876.5^{\mathrm{c}}$ & $829.2^{\mathrm{d}}$ & $965.9^{\mathrm{a}}$ & 17.42 & $<0.0001$ \\
$\mathrm{CP}$ & $127.9^{\mathrm{a}}$ & $84.56^{\mathrm{b}}$ & $70.95^{\mathrm{bc}}$ & $61.86^{\mathrm{c}}$ & $34.65^{\mathrm{d}}$ & 10.41 & 0.0009 \\
$\mathrm{NDF}$ & $700.0^{\mathrm{b}}$ & $660.0^{\mathrm{c}}$ & $690.0^{\mathrm{bc}}$ & $660.0^{\mathrm{c}}$ & $840.0^{\mathrm{a}}$ & 22.56 & 0.0002 \\
$\mathrm{ADF}$ & $380.0^{\mathrm{b}}$ & $360.0^{\mathrm{b}}$ & $370.0^{\mathrm{bc}}$ & $360.0^{\mathrm{b}}$ & $430.0^{\mathrm{a}}$ & 8.940 & 0.0024 \\
$\mathrm{ADL}$ & $40.00^{\mathrm{b}}$ & $50.00^{\mathrm{ab}}$ & $50.00^{\mathrm{ab}}$ & $70.00^{\mathrm{a}}$ & $60.00^{\mathrm{ab}}$ & 4.270 & 0.2100 \\
$\mathrm{HC}$ & $320.0^{\mathrm{b}}$ & $300.0^{\mathrm{b}}$ & $320.0^{\mathrm{b}}$ & $300.0^{\mathrm{b}}$ & $410.0^{\mathrm{a}}$ & 14.06 & 0.0025 \\
$\mathrm{NDS}$ & $300.0^{\mathrm{b}}$ & $340.0^{\mathrm{a}}$ & $310.0^{\mathrm{ab}}$ & $340.0^{\mathrm{a}}$ & $160.0^{\mathrm{c}}$ & 22.55 & 0.0002 \\
$\mathrm{ME} \mathrm{KJ} / \mathrm{kg}$ & 13.40 & 13.22 & 13.55 & 13.23 & 13.82 & 0.1682 & 0.8615 \\
\hline
\end{tabular}

$\mathrm{DM}=$ dry matter, $\mathrm{OM}=$ organic matter, $\mathrm{CP}=$ crude protein, $\mathrm{NDF}=$ neutral detergent fibre, $\mathrm{ADF}=$ acid detergent fibre, $\mathrm{ADL}=$ acid detergent lignin, $\mathrm{HC}=$ hemicellulose, $\mathrm{NDS}=$ neutral detergent soluble, $\mathrm{ME}=$ metabolizable energy. $100 \mathrm{U}=100 \%$ urea, $75 \mathrm{U} 25 \mathrm{WA}=75 \%$ urea $+25 \%$ wood ash, 50U50WA $=50 \%$ urea $+50 \%$ wood ash, $25 \mathrm{U} 75 \mathrm{WA}=25 \%$ urea $+75 \%$ wood ash, $0 \mathrm{U} 0 \mathrm{WA}=$ Untreated

Differences $(\mathrm{P}=0.0001)$ were observed for ash contents between the treated and untreated maize cobs. Treatments 0U0WA and 100U had similar organic matter contents (965.9 and $962.3 \mathrm{~g} / \mathrm{kg}$ respectively) but differed $(\mathrm{P}<0.0001)$ significantly from the other treatments. The highest CP content was recorded for treatment $100 \mathrm{U}(127.9 \mathrm{~g} / \mathrm{kg})$ and the lowest for treatment 0U0WA $(34.65 \mathrm{~g} / \mathrm{kg}) \quad(\mathrm{P}=0.0009)$. Treatments 75U25WA and 50U50WA had similar CP contents $(84.56$ and $70.95 \mathrm{~g} / \mathrm{kg})$ while $50 \mathrm{U} 50 \mathrm{WA}(70.95 \mathrm{~g} / \mathrm{kg})$ and 25U75WA $(61.86 \mathrm{~g} / \mathrm{kg})$ also had similar contents.

Untreated maize cob had the highest NDF content of $840 \mathrm{~g} / \mathrm{kg}$ while treatments $100 \mathrm{U}$, 75U25WA, 50U50WA, 25U75WA had similar NDF contents of 700, 660690 and $660 \mathrm{~g} / \mathrm{kg}$ respectively $(\mathrm{P}=0.0009)$. There was effect of treatment on $\mathrm{ADF}(\mathrm{P}=0.0024)$ with treatment 0U0WA recording the highest content of $430 \mathrm{~g} / \mathrm{kg}$. Treatments $100 \mathrm{U}, 75 \mathrm{U} 25 \mathrm{WA}, 50 \mathrm{U} 50 \mathrm{WA}$, 25U75WA had similar ADF contents of 380, 360, 370 and $360 \mathrm{~g} / \mathrm{kg}$ respectively. There were no effects $(\mathrm{P}=0.2100)$ of treatment on ADL contents of the treated and untreated maize cobs. Effect of treatments were observed for hemicellulose $(\mathrm{HC})(\mathrm{P}=0.0025)$. Treatments 100U, 75U25WA, 50U50WA, 25U75WA had 320, 300, 320 and $300 \mathrm{~g} / \mathrm{kg}$ of $\mathrm{HC}$ contents respectively and were similar but different from treatment 0UOWA which had the highest content $(410 \mathrm{~g} / \mathrm{kg})$.

Effect of treatments was observed for neutral detergent soluble (NDS) ( $\mathrm{P}=0.0002)$. Treatment 0U0WA had the lowest NDS content of $160 \mathrm{~g} / \mathrm{kg}$ while treatments $75 \mathrm{U} 25 \mathrm{WA}$ and 25U75WA recorded $340 \mathrm{~g} / \mathrm{kg}$ each. Treatments $100 \mathrm{U}$ and 50U50WA had similar NDS 
contents of 300 and $310 \mathrm{~g} / \mathrm{kg}$ respectively. No effect was observed for energy content between the treated and untreated maize cobs.

In vitro gas production characteristics of treated and untreated maize cobs are shown in Figure 1. Treatment 0U0WA had the highest gas production $(16.5 \mathrm{ml})$ at $6 \mathrm{hrs}$ of incubation and differed $(\mathrm{P}=0.0065)$ significantly from the rest of the treatments. Treatments 100U, 75U25WA, 50U50WA, 25U75WA had 9.5, 10.00, 10.50 and $10.50 \mathrm{ml}$ gas production at $6 \mathrm{hrs}$ respectively and were similar. Effect of treatment was not observed $(\mathrm{P}=0.8042)$ for gas production at $12 \mathrm{hrs}$ of incubation; however, there was effect $(\mathrm{P}=0.0012)$ at $24 \mathrm{hrs}$ of incubation. Treatments 100U and 50U50WA had similar gas production (48.50 and $47.50 \mathrm{ml})$ while treatments 75U25WA and 25U75WA also had similar gas production (45.00 and 44.50 $\mathrm{ml}$ ) at this time. The least gas production at $24 \mathrm{hrs}$ of incubation was from treatment 0U0WA (42.50 ml).Effect of treatments was observed on gas production at $48 \mathrm{hrs}$ of incubation $(\mathrm{P}=0.0001)$. Treatment 25U75WA produced the highest gas $(73.50 \mathrm{ml})$ while treatment OUOWA produced the least gas $(50.50 \mathrm{ml})$.

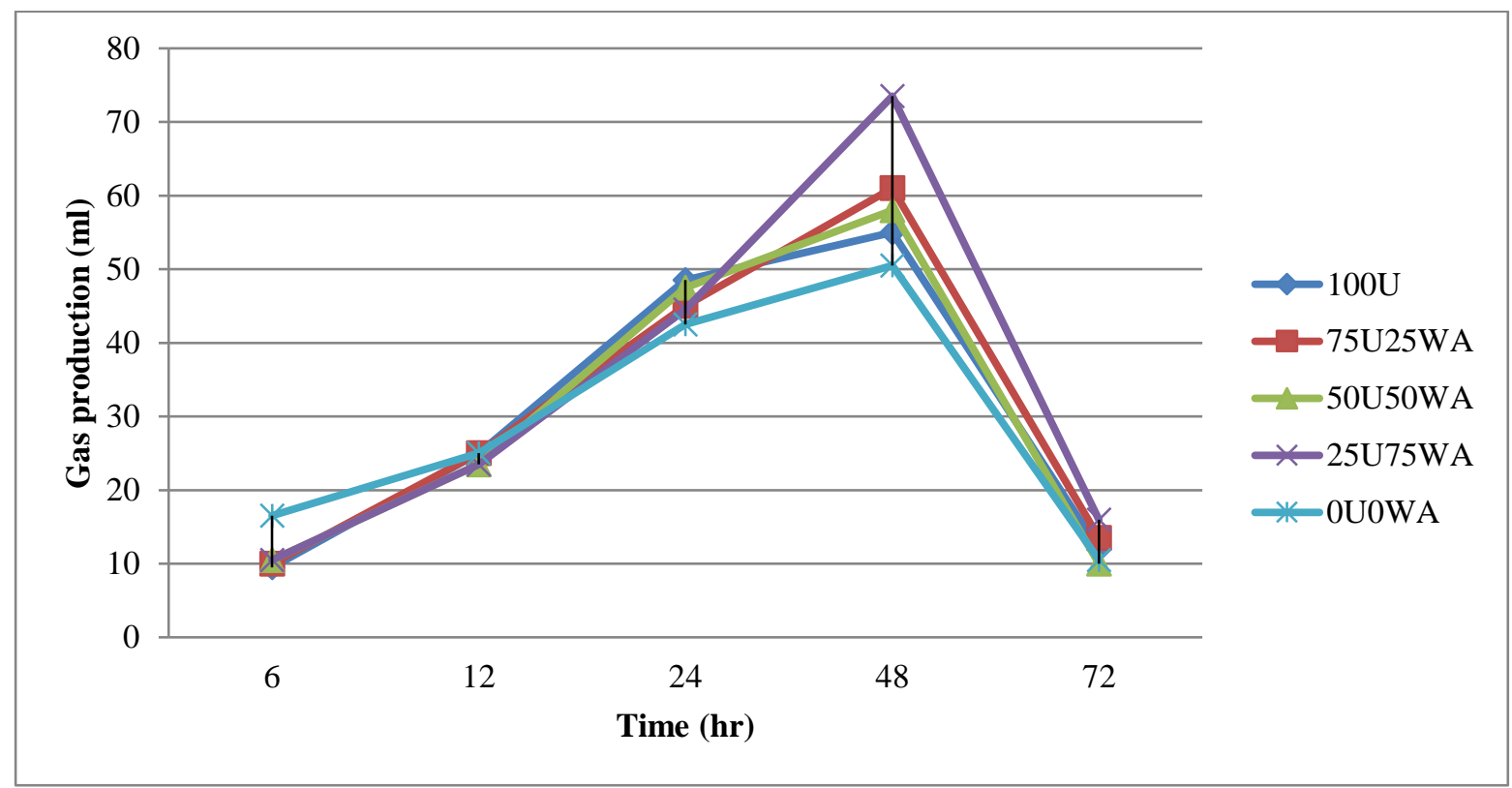

Figure 1: In vitro gas production $(\mathrm{ml} / 500 \mathrm{mg})$ of untreated and treated maize cobs Şekil 1: İ̧̧lenmemiş ve işlenmiş mısır koçanlarının in vitro gaz üretimi (ml / $500 \mathrm{mg}$ )

In vitro gas production parameters of untreated and treated maize cobs are shown in Table 2. Effect of treatment $(\mathrm{P}=0.0431)$ was observed on rapidly soluble 'a' gas production fraction. Treatment 25U75WA had the highest 'a' fraction $(8.516 \mathrm{ml})$ while treatments $100 \mathrm{U}$, 50U50WA and 0U0WA all had similar ' $a$ ' fractions. Effects of treatments $(\mathrm{P}=0.0539)$ was observed on gas production ' $\mathrm{a}+\mathrm{b}$ ' fraction. Treatment $25 \mathrm{U} 75 \mathrm{WA}$ had the highest potential gas production ' $\mathrm{a}+\mathrm{b}$ ' $(47.95 \mathrm{ml})$ while those for the rest of the treatments were similar $(39.50$, 39.86 and $36.91 \mathrm{ml})$. 
Table 2. In vitro gas production $(\mathrm{ml} / 500 \mathrm{mg})$ parameters of untreated and treated maize cobs Tablo 2. İşlenmemiş ve işlenmiş mısır koçanlarının in vitro gaz üretim ( $\mathrm{ml} / 500 \mathrm{mg}$ ) parametreleri

\begin{tabular}{llllllll}
\hline \multicolumn{7}{c}{ Treatments } \\
\hline $\begin{array}{l}\text { In vitro gas } \\
\text { production } \\
\text { parameters }\end{array}$ & $100 \mathrm{U}$ & 75U25WA & 50U50WA & 25U75WA & 0U0WA & SE & $\begin{array}{l}\text { P } \\
\text { values }\end{array}$ \\
\hline $\mathrm{b}$ & $39.60^{\mathrm{ab}}$ & $39.59^{\mathrm{ab}}$ & $39.46^{\mathrm{b}}$ & $39.43^{\mathrm{b}}$ & $40.40^{\mathrm{a}}$ & 0.1428 & 0.1366 \\
$\mathrm{c}$ & 0.0926 & 0.0864 & 0.0982 & 0.0716 & 0.0996 & 0.0048 & 0.4107 \\
$\mathrm{a}+\mathrm{b}$ & $39.50^{\mathrm{b}}$ & $39.86^{\mathrm{b}}$ & $35.74^{\mathrm{b}}$ & $49.95^{\mathrm{a}}$ & $36.91^{\mathrm{b}}$ & 1.592 & 0.0539 \\
$\mathrm{ed}$ & $29.65^{\mathrm{ab}}$ & $29.66^{\mathrm{ab}}$ & $26.50^{\mathrm{b}}$ & $36.01^{\mathrm{a}}$ & $27.53^{\mathrm{b}}$ & 1.288 & 0.1043 \\
\hline
\end{tabular}

$100 \mathrm{U}=100 \%$ urea, $75 \mathrm{U} 25 \mathrm{WA}=75 \%$ urea $+25 \%$ wood ash, 50U50WA $=50 \%$ urea $+50 \%$ wood ash, 25U75WA=25\%urea $+75 \%$ wood ash, OUOWA $=$ Untreated, $\mathrm{a}=$ gas production from soluble fraction, $\mathrm{b}=$ insoluble but fermentable gas production from insoluble but fermentable fraction, $c=$ gas production rate, $a+b=$ potential gas production, ed= effective gas production.

Truly degraded substrate (TDS), gas roduction (GP), microbial mass production (MMP), efficiency of microbial mass production (EMMP) and partitioning factor (PF) of untreated and treated maize cobs are shown in Table 3.No effect of treatments was observed $(\mathrm{P}=0.7621)$ for TDS $(\mathrm{mg})$ but observed $(\mathrm{P}=0.0110)$ for TDS $(\%)$. Treatment 25U75WA had the highest TDS (70.53\%) and similar to 50U50WA (63.89\%). Treatment 0U0WA had the lowest TDS $(45.65 \%)$. No effect $(\mathrm{P}=0.6470)$ of treatments was observed for GP at $24 \mathrm{hrs}$ of incubation. There was effect $(\mathrm{P}=0.0040)$ of treatments on MMP. Treatment 25U75WA had the highest MMP $(53.55 \mathrm{mg})$ while 0UOWA had the least $(25.20 \mathrm{mg})$. The MMP from treatment 25U75WA was similar to those of 100U, 50U50WA and 75U25WA while effect (P $=0.0005)$ of treatments was observed on EMMP. Treatment 25U75WA had the highest EMMP (23.68\%) while 0U0WA had the least (12.00\%). Treatments 100U, 75U25WA and 50U50WA had similar EMMP. Effect $(\mathrm{P}=0.0005)$ of treatments was observed on $\mathrm{PF}$ and followed the same pattern as in EMMP. Treatment 25U75WA had the highest PF (2.883) while 0U0WA had the least PF (2.500). The PF for treatments 100U, 75U25WA and 50U50WA were all statistically the same.

Table 3. In vitro truly degraded substrate parameters of treated and untreated maize cobs Tablo 3. İşlenmiş ve işlenmemiş misır koçanlarının in vitro gerçek anlamda bozulmuşsubstrat parametreleri

\begin{tabular}{llllllll}
\hline & \multicolumn{7}{c}{ Types of treatment } \\
\cline { 2 - 7 } Parameters & $100 \mathrm{U}$ & $75 \mathrm{U} 25 \mathrm{WA}$ & $50 \mathrm{U} 50 \mathrm{WA}$ & $25 \mathrm{U} 75 \mathrm{WA}$ & 0U0WA & SE & $\begin{array}{l}\text { P } \\
\text { values }\end{array}$ \\
\hline TDS (mg) & 212.5 & 216.3 & 221.3 & 226.3 & 210.0 & 3.772 & 0.7621 \\
TDS (\%) & $55.62^{\mathrm{bc}}$ & $59.84^{\mathrm{b}}$ & $63.89^{\mathrm{ab}}$ & $70.53^{\mathrm{a}}$ & $45.65^{\mathrm{c}}$ & 2.933 & 0.0110 \\
GP(24hrs)(ml) & 77.00 & 77.50 & 80.50 & 78.50 & 84.00 & 1.447 & 0.6470 \\
MMP(mg) & $43.10^{\mathrm{b}}$ & $45.75^{\mathrm{ab}}$ & $44.15^{\mathrm{ab}}$ & $53.55^{\mathrm{a}}$ & $25.20^{\mathrm{c}}$ & 3.221 & 0.0040 \\
EMMP & $20.32^{\mathrm{b}}$ & $21.13^{\mathrm{b}}$ & $19.92^{\mathrm{b}}$ & $23.68^{\mathrm{a}}$ & $12.00^{\mathrm{c}}$ & 1.329 & 0.0005 \\
PF & $2.761^{\mathrm{b}}$ & $2.790^{\mathrm{b}}$ & $2.748^{\mathrm{b}}$ & $2.883^{\mathrm{a}}$ & $2.500^{\mathrm{c}}$ & 0.1682 & 0.0005 \\
\hline
\end{tabular}

$100 \mathrm{U}=100 \%$ urea, $75 \mathrm{U} 25 \mathrm{WA}=75 \%$ urea $+25 \%$ wood ash, $50 \mathrm{U} 50 \mathrm{WA}=50 \%$ urea $+50 \%$ wood ash, $25 \mathrm{U} 75 \mathrm{WA}=25 \%$ urea $+75 \%$ wood ash, $0 \mathrm{U} 0 \mathrm{WA}=$ Untreated, TDS $=$ truly degraded substrate, GP $=$ gas production at 24 hours, $\mathrm{MMP}=$ microbial mass production, $\mathrm{EMMP}=$ efficiency of microbial mass production, $\mathrm{PF}=$ partitioning factor. 


\section{Discussion}

The ash content of the 25U75WA was highest because it had the highest inclusion rate of wood ash. As can be observed, the ash content increased as the amount of wood ash substitution also increased, which is in agreement with the findings of other workers (Adebowale et al., 1991; Imbeah, 1999; Ramirez et al., 1991; Nolte et al.,1987). Treatment of maize cobs with $100 \%$ urea led to increase in its CP contents, however, when portions of the urea were substituted with wood ash, the CP contents reduced. Several authors have also reported increases in CP contents of urea treated crop residues (Preston, 1985; FAO, 2002; Fall et al., 1989; Chenost, 1995; Rahman et al., 2009). Sundstol, (1985) treated crop residues using a combination of urea and lime with the hope of incorporating nitrogen from urea and calcium from lime into the treated crop residues. It has also been reported that combinations of urea and lime inhibit mould formation as a result of the action of ammonia generated by urea compared to when lime was used alone for treatments (Zaman and Owen, 1990; Zaman et al., 1994; Trach et al., 2001). The combinations of urea and wood ash in maize cobs treatment therefore has the advantage of increasing CP contents, inhibition of mould formation at the same time incorporating minerals from wood ash.

Individually urea and wood ash have been implicated in the reduction of NDF and ADF contents of crop residues (Preston, 1985; FAO, 2002; Fall et al., 1989; Chenost, 1995; Adebowale, 1985; Imbeah, 1999; Ramirez et al., 1991; Nolte et al., 1987). It has been reported that alkali from lime which is more potent than ash solution was stronger than ammonia released during treatment of crop residues (Chaudhry, 1998). Therefore, a combination of urea and wood ash would then be synergistically beneficial. Indeed this was observed in the current study where cobs treated with $25 \%$ urea combined with $75 \%$ WA had their NDF and ADF reduced significantly compared to those treated with $100 \%$ urea. The same effect was reflected in the hemicellulose where those of the untreated remained high. This implied that the synergistic effect of combining both urea and wood ash were more efficacious in reducing both the NDF and ADF contents of maize cobs compared to when urea was used alone probably because the combination of alkali in wood ash and urea was more potent than the ammonia generated by urea treatment alone (Chaudhry, 1998). According to Makkar (2003), urea was efficient in disrupting lignin-carbohydrate complexes, thus improving fibre digestion and also increasing the nitrogen contents of feed. Jackson (1977) attributed the decrease in fibre content to the disruption of the cell wall by solubilizing hemicelluloses, lignin and silica, hydrolyzing uronic acid, acetic acid esters and swelling cellulose.

Van Soest (1964) reported that NDF and ADF were negatively related to voluntary dry matter intake (VDMI) in sheep fed forage diet and that NDF was more related to VDMI than ADF in both legumes and grasses. Jung and Allen (1995) reported that VDMI would increase in ruminants consuming forages with low NDF content. The NDF content of forage has been reported as the best chemical predictor of VDMI (Waldo, 1986). It is therefore evidently clear that perhaps treatment 25U75WA would result in increase in VDMI due to reduction in NDF and ADF contents of maize cobs. The neutral detergent soluble (NDS) of 25U75WA were also higher $(340 \mathrm{~g} / \mathrm{kg})$ than those of the $100 \mathrm{U}$-treated $(300 \mathrm{~g} / \mathrm{kg})$, implying that treatment 25U75WA resulted in richer cell soluble materials that would be readily available to the 
rumen microbes. The untreated maize cobs had the highest hemicellulose compared to the treated which may not be readily available for microbial degradation due to its association with lignin than any other polysaccharide fraction and its bonding to phenolic compounds (Van Soest et al., 1991; Tuah and Orskov, 1989).

The gas production characteristics for the treated and untreated maize cobs indicated that at $48 \mathrm{hrs}$ of incubation, treatment 25U75WA had the highest gas production $(73.00 \mathrm{ml})$ while treatments $100 \mathrm{U}$ and 0UOWA had 55.00 and $50.50 \mathrm{ml}$ respectively. Treatment 25U75WA also had the highest gas production ' $a$ ' and ' $a+b$ ' fractions, indicating its superiority over the rest of the treatments. Gas production alone however may not be used to characterize quality of feed since some of the gases produced are products of bicarbonate buffer and not from substrate fermentation (Makkar, 2010). More information can only be generated from its in vitro truly degraded substrate parameters. Measurement of gas alone with time only implies the measurement of nutritional wasteful and environmentally hazardous products $\left(\mathrm{CO}_{2}\right.$ and $\left.\mathrm{CH}_{4}\right)$ (Makkar, 2010). In order to select feeds with high microbial efficiency, adoption of gas measurements alone, which is a reflection of short chain fatty acids (SCFA), would be misleading and might result in selection against maximum microbial mass yield (Blummel et al., 1997; Makkar, 2010). It is, therefore, necessary to determine the truly degraded substrate parameters concomitantly with the gas production profile in order to have a more reliable result.

Despite the fact that the untreated maize cobs (OUOWA) had the highest gas production at $24 \mathrm{hrs}$, treatment 25U75WA had the highest percent truly degraded substrate (TDS) which corroborated the assertion that gas production only should not be used for characterization of feed qualities since some of the gases could have been generated from the buffering of bicarbonate buffer (Blummelet al., 1997; Makkar, 2010). Treatment OUOWA had the least microbial mass production and partitioning factor (PF) while the highest was recorded for treatment 25U75WA. Presence of higher ash contents in 25U75WA might have catalyzed rapid microbial multiplication hence more attachment to fibre and digestion. Higher concentrations of microbial mass production in 25U75WA imply availability of more ruminal microbes that would be enzymatically digested at the hind gut to the benefit of the host animal. Several authors have suggested that substrates should be selected based on high PF and TDS but low gas production (Blummel et al., 1997; Makkar, 2010). Based on data presented by this study, it would appear that perhaps 25U75WA could be the treatment of choice.

\section{Conclusion}

It was concluded that, treatment with $25 \%$ urea combined with $75 \%$ WA $(1.25 \mathrm{~kg}$ urea mixed with $22.5 \mathrm{~kg}$ WA in 100 liters of water $200 \mathrm{~kg}$ maize cobs) could improve the chemical composition, gas production and TDS parameters of maize cobs.

\section{Acknowledgement}

Tertiary Education Trust Fund (TETFUND) Abuja, Nigeria is hereby acknowledged for the research grant. 


\section{References}

Abdulazeez A., Tsopito C.M., Madibela O.R., Kamau J.M., 2016. Effect of Substituting Maize Grain with Urea Wood Ash Treated Maize Cobs on Chemical Composition, in Sacco Degradation and in Vitro Gas Production Parameters. Journal of Animal Science Advances. 6 (2): 1-8.

Adebowale, E.A., 1985. Organic waste ash as source of alkali for animal feed treatment. Animal Feed Science and Technology 13: 237-248.

Adebowale, E.A., Orskov, E.R., Shand, W.J., 1991. Use of ash of cocoa pod husk as source of alkali for upgrading agricultural residues with or without hydrogen peroxide. Tropical Agriculture. 68: 27-32.

AOAC, 1999. Official Methods of Analysis, $16^{\text {th }}$ ed. Official Methods of Analysis of AOAC International, Gaithersburg, MD, USA.

Blummel, M., Steingass, H., Becker, K., Soller, H., 1997. The relationship between in vitro gas production, in vitro microbial mass yield and ${ }^{15} \mathrm{~N}$ incorporation and its implications for the prediction of voluntary feed intake of roughages British Journal Nutrition. 77: $911-921$.

Chaudhry, A.S., 1998. Chemical and biological procedures to upgrade cereal straws for ruminants. Nutritional Abstracts and Reviews. Volume 68: 319-331.

Chenost, M., 1995. Optimizing the Use of Poor Quality Roughage through Treatments and Supplementation in Warm Climate Countries with Particular Emphasis on Urea Treatment. First Electronic Conference on Tropical Feeds with Particular Emphasis on Urea Treatment FAO, Rome.

Fall, S., Guerin, H., Sall, C., Mbaye, N.D., 1989. Cereal straws in the feeding system of ruminant in Senegal. Overcoming constraints to the efficient utilization of agricultural byproducts as animal feed In: Adegabola, A. A., J.A., Kategile, D.A. Little, (eds), Proceedings of the Fourth Annual Workshop Held at the Institute of Animal Research Mankon Station African Research Network for Agricultural Byproducts (ARNAB), Addis Ababa, Ethiopia.

FAO, (Food and Agriculture Organization of the United Nations) 2002. Animal Production Based on Crop Residues; China's Experiences. FAO Animal Production and Health Paper No. 149. pp 39.

Jackson, M.G., 1977. Review article. The alkali treatment of straws. Animal Feed Science and Technology. 2:105-130.

Jung, H.G., Allen, M.S., 1995. Characteristics of plant cell walls affecting intake and digestibility of forages by ruminants. Journal of Animal Science 73: 2274-2290.

Makkar, H.P.S., 2003. Quantification of Tannins in Tree and Shrub Foliage. A Laboratory Manual Kluwer Academic Publishers, Dordrect, The Netherlands, pp 102.

Makkar, H.P., 2010. In Vitro Screening of Feed Resources for Efficiency of Microbial Protein Synthesis. In: Vercoe, P., H. P. S., Makkar, A. Schlink, (eds) In vitro screening of plant resources for extra-nutritional attributes in ruminants: nuclear and related methodologies. Springer, Dordrecht. 
Menke, K.H., Steingass, H., 1988. Estimation of the energetic feed value obtained from chemical analysis and in vitro gas production using rumen fluid. Animal Research and Development. 28: 7-55.

Nolte, M.E., Cline, J.H., Dehority, B.A., Loerch, S.C., Parker, C.F., 1987. Treatment of wheat straw with alkaline solutions prepared from wood ashes to improve fibre utilization by ruminant. Journal of Animal Science 64: 669-677.

Nordblom, J.L., Shomo, F., 1995. Food and Feed prospects to 2020 in the West Asia North Africa region. ICARDA Social Science Paper No 2, International Centre for Agricultural Research in the Dry Areas, Aleppo, Syria.

Preston, T.R., 1985. Strategies for Optimizing the Utilization of Crop Residues and Agro industrial Byproducts for Livestock Feeding in Tropics. Towards Optimal of Agricultural By-products to Livestock in Africa . Proceedings of a Workshop held at the University of Alexandria. International Livestock Center for Africa (ILCA), Egypt pp17.

Rahman, M.M., M.A. Akbar., K.M.S. Islam., A.B.M. Khaleduzzaman and A.B.M.R. Bostami, 2009. Nutrient Digestibility And Growth Rate Of Bull Calves Fed Rice Straw Treated With Wood Ash Extract. Bangladesh Journal of Animal Science. 38: $45-52$

Ramirez, R.G., 1991. Wood ash, sodium hydroxide and urine to increase sorghum straw utilization by sheep. Small Ruminant Research. 5: 83-92.

SAS, 2002. Statistical Analysis System. SAS user's guide: Statistics, SAS Inst. Inc., Carry, NC.

Solomon, A.K., Ulfina, G.G., Gemeda, D.J., 2012. The potential of treatment with ash solution in improving degradability of fibrous feeds in Ethiopia Agricultural Science Research Journal. 3: 100-105.

Steel, R.G.D., Torrie, J.H., 1984. Principles and Procedures of Statistics. A Biometrical Approach ( $\left.2^{\text {nd }} E d\right)$. McGraw Hill Book Co. Inc. New York. USA.

Sundstol, F., 1985. Recent advances in development and utilization of chemically treated low quality roughages. In: (Eds. M. Wanapat, C. Devendra). Relevance of Crop Residues as Animal Feeds in Developing Countries. Funny Press. Bangkok. Thailand. pp 121145.

Trach, N.X., Mo, M., Cu, X.D., 2001. Effects of treatment of rice straw with lime and/or urea on its chemical composition, in-vitro gas production and rumen degradation. Livestock Research for Rural Development .13:4 Article \#35 https://www.lrrd.org/lrrd13/4/trac134a.htm.

Tuah, A.K., Orskov, E.R., 1989. A study on the degradation of untreated, ammonia treated, sodium hydroxide treated and water-soaked corncob and cocoa pod husk in the rumen using nylon bag technique. In: (Eds. A.N. Said., J.A. Kategile and B.H. Dzowela), Overcoming constraints to the efficient utilization of agricultural by-products as animal feed. Proceedings of $4^{\text {th }}$ ARNAB Workshop held in Bamenda, Cameroon, 20 - 27 Oct, 1987 ILCA publication pp 363-373.

Van Soest, J.P., 1964. Symposium on factors influencing the voluntary intake of herbage by ruminants: voluntary intake in relation to chemical composition and digestibility. 
Presented at the meeting of the North Atlantic Section. ASAS July 20-22, 1964 at Cornel University, Ithaca, New York.

Van Soest, P.J., Robertson, H.B., Lewis, B.A., 1991. Methods of dietary fibre, NDF and nonstarch polysaccharides in relation to animal material. Journal of Dairy Science. 74: 3583- 3595.

Waldo, D.R., 1986. Effect of forage quality on intake and forage concentrate interactions. Journal of Dairy Science. 69: 617-631.

Zaman, M.S., E. Owen and D.J. Pike, 1994. The calculation method used for optimizing conditions of treatment of barley straw with calcium hydroxide and urea, moisture, treatment time and temperature on in-vitro digestibility. Animal Feed Science Technology. 45: 271-282.

Zaman, M.S. and E. Owen, 1990. Effect of calcium hydroxide or urea treatment of barley straw on intake and digestibility in sheep. Small Ruminant Research. 3: 237-248. 